


\section{Brazil in the world}

\section{MANCHESTER 1824}

Manchester University Press 
Sean W. Burges - 9781526108043 Downloaded from manchesterhive.com at 04/26/2023 06:06:12AM via free access 


\section{Brazil in the world}

The international relations of a

South American giant

\section{Sean W. Burges}

Manchester University Press 
Copyright @ ( Sean W. Burges 2017

The right of Sean W. Burges to be identified as the author of this work has been asserted by him in accordance with the Copyright, Designs and Patents Act 1988.

Published by Manchester University Press

Altrincham Street, Manchester M1 7JA

www.manchesteruniversitypress.co.uk

British Library Cataloguing-in-Publication Data

A catalogue record for this book is available from the British Library

Library of Congress Cataloging-in-Publication Data applied for

ISBN 9781526107398 hardback

ISBN 9781526107404 paperback

First published 2017

The publisher has no responsibility for the persistence or accuracy of URLs for any external or third-party internet websites referred to in this book, and does not guarantee that any content on such websites is, or will remain, accurate or appropriate.

Typeset in Sabon and Gill Sans by

Servis Filmsetting Ltd, Stockport, Cheshire 